\title{
Thermal decomposition of allantoin as probed by matrix isolation FTIR spectroscopy
}

\author{
N. Kuş ${ }^{\text {a,b }}$, S. Haman Bayar ${ }^{c}$, R. Fausto ${ }^{\text {b,* }}$ \\ ${ }^{a}$ Department of Physics, Anadolu University, 26470 Eskişehir, Turkey \\ ${ }^{\mathrm{b}}$ Department of Chemistry, University of Coimbra, P-3004-535 Coimbra, Portugal \\ ${ }^{\mathrm{c}}$ Hacettepe University, Faculty of Education, Department of Physics, 06800 Beytepe, Ankara, Turkey
}

\section{A R T I C L E I N F O}

\section{Article history:}

Received 19 August 2009

Received in revised form

18 September 2009

Accepted 23 September 2009

Available online 25 September 2009

\section{Keywords:}

Allantoin

Conformational analysis

DFT calculations

Low temperature matrix isolation and room temperature crystalline state IR spectra Thermal decomposition

\begin{abstract}
A B S T R A C T
The optimized geometries, energies of the possible conformers of allantoin (2,5-dioxo-4-imidazolidinyl urea, the diureide of glyoxylic acid) as well as the barriers for conformational interconversion have been calculated using the density functional theory [DFT(B3LYP)/6-311++G(d,p)] method. The calculations predicted the existence of four conformers $\left(\mathbf{g C}, \mathbf{t T}, \mathbf{g}^{\prime} \mathbf{C}\right.$, and $\mathbf{g}^{\prime} \mathbf{T}$; where the first and second symbols in the name of the conformers designate the conformation around the exocyclic NHC-NHCO and $\mathrm{CNH}-\mathrm{CO}$ axes, respectively), with the $\mathbf{g C}$ form contributing to more than $98 \%$ of the population in gas phase at room temperature. This conformer is different from that corresponding to the monomeric unit found in crystalline RS-allantoin ( $\mathbf{g}^{\prime} \mathbf{C}$; Mootz, D. Acta Crystallogr. 1965, 19, 726), stressing the importance of intermolecular $\mathrm{H}$-bonding in determining the structure of the crystal. Upon sublimation under vacuum $\left(10^{-6} \mathrm{mbar}\right)$, the compound was found to undergo extensive decomposition to urea, isocyanic acid, $\mathrm{NH}_{3}$, and carbon. The identification of the decomposition products was made by using matrix isolation infrared spectroscopy. In consonance with the theoretical predictions, the allantoin molecules surviving thermal decomposition were found to undergo conformational isomerization and be present in the cryogenic argon matrix in both the $\mathbf{g C}$ and $\mathbf{g} \mathbf{C}$ conformations. The solid state room temperature infrared spectrum of allantoin was also investigated and assigned.
\end{abstract}

(c) 2009 Elsevier Ltd. All rights reserved.

\section{Introduction}

Allantoin (2,5-dioxo-4-imidazolidinyl urea; $\mathrm{C}_{4} \mathrm{H}_{6} \mathrm{~N}_{4} \mathrm{O}_{3}$; Fig. 1 ) is also called 5-ureidohydantoin or glyoxyldiureide and is the diureide of glyoxylic acid. It is a product of purine metabolism and known

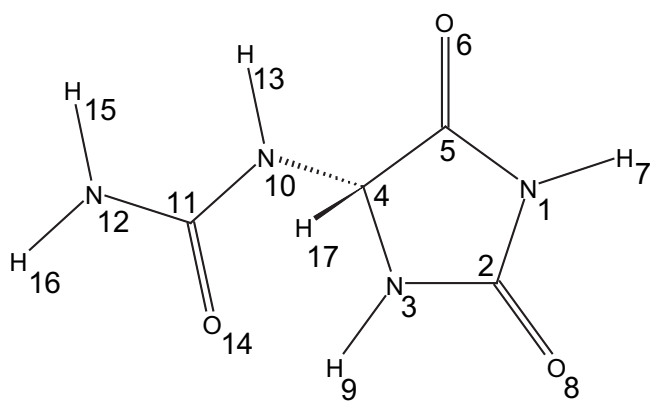

Figure 1. Allantoin, with the adopted atom labeling scheme.

\footnotetext{
* Corresponding author. Tel.: +351 239 852080; fax: +351 239827703

E-mail address: rfausto@ci.uc.pt (R. Fausto).
}

since long ago to exist in nature, for example, in allantoic and amniotic fluids, in fetal urine and in many plants and bacteria. ${ }^{1-8} \mathrm{Al}-$ lantoin is active in skin-softening and rapid skin cells regeneration. It removes corneocytes by loosening the intercellular kit or the desmosomes (protein bridges) that maintain the adhesion of corneocytes to each other. It then exfoliates dry and damaged cells and boosts the radiant appearance of the skin, whose surface becomes smoother and softer. Due to these properties, allantoin has been used in cosmetic industry in several forms (e.g., lotions, creams, suntan products, shampoos, lipsticks, and various aerosol preparations), as well as in topical pharmaceutical preparations for treatment of skin diseases for many years. ${ }^{4,9-11}$

From a more fundamental perspective, allantoin is also an interesting compound, in which different types of intra- and intermolecular $\mathrm{H}$-bond interactions can be expected to be relevant in determining its structural preferences, spectroscopic properties, and reactivity. In particular, the fragmentation reactions exhibited by the compound appeared to us particularly appealing for investigation since the structure of the allantoin ring, with two sequential $-\mathrm{C}(=\mathrm{O})-$ $\mathrm{N}(\mathrm{H})$ - fragments, looked a good candidate to act as a precursor of isocyanic acid, a well known biologically pernicious substance that can easily react with amino terminus residues of proteins (or side chains of lysine and arginine residues) to form carbamoylated 
proteins, which have been observed in several states of disease. ${ }^{12-15}$ Indeed, 1-phenyl-tetrazolone, which has structural similarities to allantoin possessing a single $-\mathrm{C}(=\mathrm{O})-\mathrm{N}(\mathrm{H})$ - fragment in its heterocyclic ring has been recently shown to decompose easily to phenylazide and isocyanic acid. ${ }^{16}$

In spite of both its many applications and expected interesting molecular properties and reactivity, allantoin has not yet been much studied from the structural point of view, though many publications describe procedures for its analytical determination, in particular in a biochemical context. ${ }^{17-20}$ The molecule has a chiral center and may then exist as $R$ - and $S$-enantiomeric forms. Contrary to what happens for the enantiomerically pure substance, for which no crystal data has yet been reported, the crystalline structure of $R S$-allantoin was obtained by X-ray diffraction. ${ }^{21}$ The crystal was found to belong to the $P 2_{1} / c$ space group $(a=8.024, b=5.153$, $c=14.797 \AA, \beta=93.01^{\circ}$ ), with four molecules in the unit cell, exhibiting an intricate three-dimensional $\mathrm{H}$-bond network in which the three carbonyl oxygens, three imido, and two amino hydrogen atoms take part. The monomeric unit in the crystal was found to have the $\mathrm{C}_{4}-\mathrm{N}_{10}-\mathrm{C}_{11}-\mathrm{O}_{14}$ axis in the cis conformation and a conformation around the $\mathrm{C}_{4}-\mathrm{N}_{10}$ bond that directs the $\mathrm{O}_{14}$ atom to above the heterocyclic ring, so that the molecule assumes a 'scorpion like' geometry. ${ }^{21}$

Kahn and Tipton ${ }^{22}$ performed simple HF/6-31G(d,p) calculations on the isolated molecule of allantoin and reported the existence of four different conformers, with the form similar to the monomeric structure found in the $R S$-allantoin crystal being the second most stable one. According to the $\mathrm{HF} / 6-31 \mathrm{G}(\mathrm{d}, \mathrm{p})$ calculations, the most stable conformer (by $12.8 \mathrm{~kJ} \mathrm{~mol}^{-1}$ ) has also a cis $\mathrm{C}_{4}-\mathrm{N}_{10}-\mathrm{C}_{11}-\mathrm{O}_{14}$ axis, but in this case the ureido group is directed toward the outside part of the molecule. Two additional conformers of higher energy bearing a trans $\mathrm{C}_{4}-\mathrm{N}_{10}-\mathrm{C}_{11}-\mathrm{O}_{14}$ fragment were also described by Kahn and Tipton. ${ }^{22}$ NMR data ${ }^{22}$ showed that in solution of both DMSO or $\mathrm{CHCl}_{3}$ allantoin should exist in a conformation with a cis $\mathrm{C}_{4}-\mathrm{N}_{10}-\mathrm{C}_{11}-\mathrm{O}_{14}$ axis as well, though no precise identification of the relevant form could be undertaken.

Previously reported reactivity studies on allantoin have focused mainly on its racemization reaction..$^{22,23}$ To the best of our knowledge, no further structural or spectroscopic studies were reported on allantoin hitherto.

In the present investigation, we performed a detailed study of the potential energy surface of allantoin using the density functional theory (DFT) approach and investigated the thermal fragmentation of the compound taking place upon sublimation. The identification of the decomposition products was made by using matrix isolation infrared spectroscopy. In addition, we obtained and assigned the room temperature infrared spectrum of the compound. This enabled us to obtain further information on the most relevant intermolecular interactions that stabilize the $\mathbf{g}^{\prime} \mathbf{C}$ conformer in this phase over the thermodynamically most stable gC conformer.

\section{Experimental and computational methods}

Allantoin was provided by Prof. Mustafa Korkmaz, Hacettepe University, Ankara, spectroscopic grade ( $>98 \%$ ). The matrices were prepared by co-deposition of argon (99.99990\% purity, obtained from Air Liquide) and the vapors generated upon sublimation of allantoin onto the cooled ( $10 \mathrm{~K}$ ) CsI substrate of the cryostat (APD Cryogenics close-cycle helium refrigeration system with a DE-202A expander). A glass vacuum system and standard manometric procedures were used to deposit the isolating gas. Allantoin was placed in a specially designed mini-oven assembled inside the cryostat and thermoelectrically heated.

The matrix isolation IR spectra were collected, with $0.5 \mathrm{~cm}^{-1}$ spectral resolution, on a Nicolet 6700 Fourier Transform infrared spectrometer, equipped with a deuterated triglycine sulfate (DTGS) detector and a $\mathrm{Ge} / \mathrm{KBr}$ beamsplitter. The infrared spectrum of the neat $R S$-allantoin crystal in $\mathrm{KBr}$ pellet at room temperature was obtained in a BOMEM MB104 FTIR spectrometer, with resolution $4 \mathrm{~cm}^{-1}$.

Differential Scanning Calorimetry (DSC) measurements were made in a Perkin-Elmer DSC7 calorimeter over the temperature range $25-255^{\circ} \mathrm{C}$, with scanning rate $10^{\circ} \mathrm{C} \mathrm{min}^{-1}$. Data acquisition and determination of the onset temperatures were performed with the Perkin-Elmer 1020 Series Thermal Analysis System Software. The samples were hermetically sealed in aluminum pans, and an empty pan was used as reference. A $20 \mathrm{~mL} \mathrm{~min}^{-1}$ nitrogen purge was employed. Temperature calibration 24 was performed with high grade standards, namely biphenyl $\left(T_{\text {fus }}=68.93 \pm 0.03{ }^{\circ} \mathrm{C}\right)$ and zinc $\left(T_{\text {fus }}=419.53^{\circ} \mathrm{C}\right)$, and verified with naphthalene $\left(T_{\text {fus }}=80.20 \pm 0.04{ }^{\circ} \mathrm{C}\right)$, benzoic acid $\left(T_{\text {fus }}=122.35 \pm 0.02{ }^{\circ} \mathrm{C}\right)$, and in$\operatorname{dium}\left(T_{\text {fus }}=156.60^{\circ} \mathrm{C}\right)$. For heat calibration the enthalpy of fusion of indium was used $\left(\Delta_{\text {fus }} H=3286 \pm 13 \mathrm{~J} \mathrm{~mol}^{-1}\right){ }^{24}$

The quantum chemical calculations were performed with the Gaussian 03 suit of programs ${ }^{25}$ at the DFT level of theory, using the $6-311++G(d, p)$ basis set. ${ }^{26,27}$ The three-parameter hybrid density functional abbreviated as B3LYP, which includes Becke's gradient exchange correction ${ }^{28}$ and the Lee, Yang and Parr, ${ }^{29}$ and Vosko, Wilk and Nusair correlation functionals ${ }^{30}$ was selected for the calculations. Structures were optimized using the Geometry Direct Inversion of the Invariant Subspace (GDIIS) method, ${ }^{31,32}$ with the transition state structures for conformational interconversion located using the Synchronous Transit-Guided Quasi-Newton (STQN) approach. $^{33}$ The $2 \mathrm{D}$ potential energy surface maps were built by varying the $\mathrm{N}_{3}-\mathrm{C}_{4}-\mathrm{N}_{10}-\mathrm{C}_{11}$ and $\mathrm{C}_{4}-\mathrm{N}_{10}-\mathrm{C}_{11}-\mathrm{O}_{14}$ dihedral angles from 0 to $360^{\circ}$ in increments of $5^{\circ}$ and optimizing all other structural parameters at the selected level of theory.

Vibrational frequencies were calculated at the same level of theory and scaled down by a single factor $(0.978)$ to correct them mainly for the effects of basis set limitations, neglected part of electron correlation and anharmonicity effects, and used to assist the analysis of the experimental spectra. Normal coordinate analysis of allantoin was undertaken in the internal coordinates space as described by Schachtschneider, ${ }^{34}$ using the program BALGA and the optimized geometries and harmonic force constants resulting from the DFT(B3LYP)/6-311++G(d,p) calculations.

\section{Results and discussion}

\subsection{Conformational analysis}

Allantoin has a chiral center, the two enantiomers being conformationally and spectroscopically equivalent. In this study we will then consider only one of the enantiomers ( $S$ form).

According to the 2D potential energy map shown in Figure 2, at least four conformers differing in the $\mathrm{N}_{3}-\mathrm{C}_{4}-\mathrm{N}_{10}-\mathrm{C}_{11}$ and $\mathrm{C}_{4}-\mathrm{N}_{10}-$ $\mathrm{C}_{11}-\mathrm{O}_{14}$ dihedral angles were expected for the molecule. This number could, eventually, increase if the heterocyclic ring deviated from planarity and the imide and amide groups were pyramidalized. Hence, a detailed search for conformers was undertaken by varying the initial geometries of the imide and amide groups and also including structures with a non-planar heterocyclic ring in the set of structures submitted to full geometry optimization. All these structures corresponded to geometries located in the vicinity of the four general minima found in the preliminary relaxed scan performed to build the 2D potential energy map provided in Figure 2.

The final number of located different energy minima was 6 (Fig. 3). Nevertheless, as discussed in detail below, these six minima correspond to only four conformational states, each one associated with one of the four low potential energy valleys represented in Figure 2. 


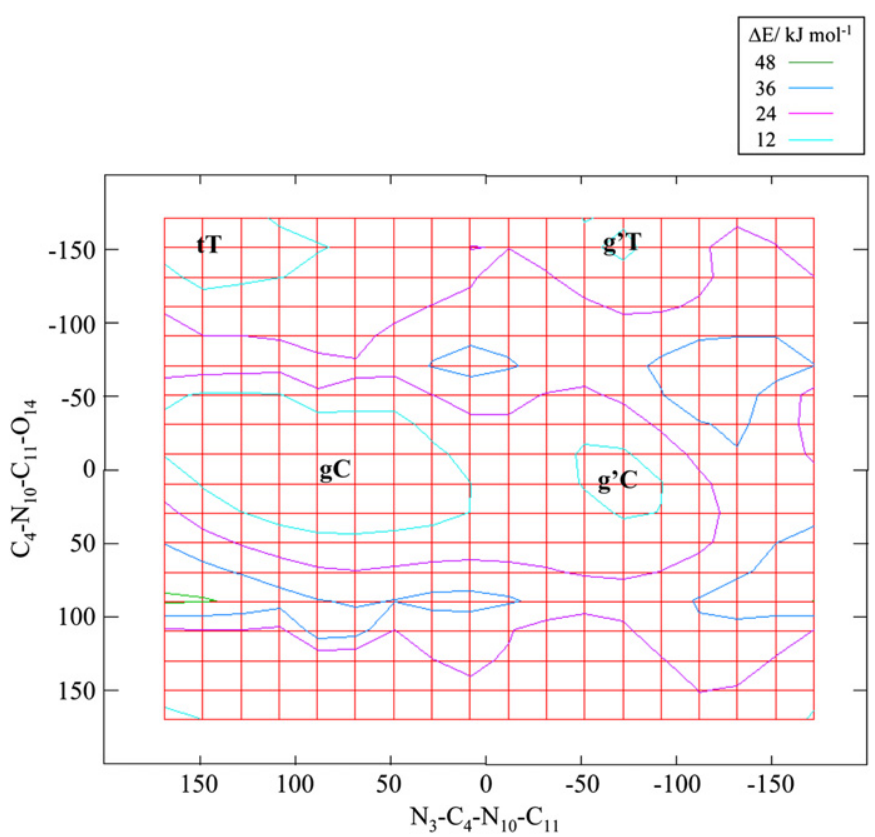

Figure 2. Potential energy map for allantoin. The map resulted from a relaxed potential energy scan where the $\mathrm{N}_{3}-\mathrm{C}_{4}-\mathrm{N}_{10}-\mathrm{C}_{11}$ and $\mathrm{C}_{4}-\mathrm{N}_{10}-\mathrm{C}_{11}-\mathrm{O}_{14}$ dihedral angles were varied from 0 to $360^{\circ}$ in increments of $5^{\circ}$ and all other structural parameters optimized at the DFT/B3LYP/6-311++G(d,p) level of theory. The plot shows four valleys, which were then fully explored for identification of the conformers of the molecule (see text for details).

In the $60 / 0^{\circ}$ valley $\left(\mathrm{N}_{3}-\mathrm{C}_{4}-\mathrm{N}_{10}-\mathrm{C}_{11} / \mathrm{C}_{4}-\mathrm{N}_{10}-\mathrm{C}_{11}-\mathrm{O}_{14}\right)$, two minima were located ( $\mathrm{I}$ and $\mathrm{I}^{\prime}$ ), which differ mainly in the geometry of the exocyclic $\mathrm{NH}_{2}$ and $\mathrm{NH}$ groups (see Fig. 3) and are separated from each other by a transition state whose energy is less than $0.01 \mathrm{~kJ} \mathrm{~mol}^{-1}$ above that of the highest energy I' minimum. So, in practical terms, I and $\mathrm{I}^{\prime}$ can be seen as a single conformer: the highest energy $\mathrm{I}^{\prime}$ form can be considered as a vibrationally excited state of I, because the barrier separating this form from I is below its zero point energy level. According to the values of its $\mathrm{N}_{3}-\mathrm{C}_{4}-\mathrm{N}_{10}-\mathrm{C}_{11}$ and $\mathrm{C}_{4}-\mathrm{N}_{10}-\mathrm{C}_{11}-$ $\mathrm{O}_{14}$ dihedral angles, we named minimum I as conformer $\mathbf{g C}$. This is the lowest energy minimum of allantoin.

Single minima were located both in the $180 / 180^{\circ}$ and $-60 / 180^{\circ}$ valleys, corresponding to the $\mathbf{t} \mathbf{T}$ and $\mathbf{g}^{\prime} \mathbf{T}$ conformers, respectively (Fig. 3). These forms are higher in energy than $\mathbf{g C}$ by ca. 11 and $18 \mathrm{~kJ} \mathrm{~mol}^{-1}$.

Finally, in the $-60 / 0^{\circ}$ valley, like in the $60 / 0^{\circ}$ valley, two minima

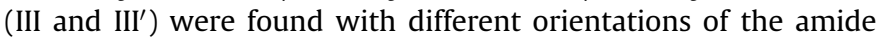
group (Fig. 3), but also in this case the highest energy minimum $\left(\mathrm{III}^{\prime}\right)$ is better described as a vibrationally excited state of the lowest energy minimum (III). Minimum III corresponds to the $\mathbf{g}^{\prime} \mathbf{C}$ conformer of allantoin, which has a relative energy of ca. $14 \mathrm{~kJ} \mathrm{~mol}^{-1}$.

Table 1 summarizes the energetic data resulting from the calculations, including the barriers for conformational isomerization between the different forms. The calculated optimized geometries for the six minima found on the potential energy surface of allantoin are provided as Supplementary data (Table S1).

It is easy to conclude that the relative stability of the conformers results mainly from the different $\mathrm{H}$-bond like interactions they exhibit. The most stable $\mathbf{g c}$ conformer possesses two considerably strong $\mathrm{N}-\mathrm{H} \cdots \mathrm{O}=$ bonds $\left(\mathrm{N}_{3}-\mathrm{H}_{9} \cdots \mathrm{O}_{14}=\right.$ and $\left.\mathrm{N}_{10}-\mathrm{H}_{13} \cdots \mathrm{O}_{6}=\right)$, which justify its comparatively low energy. The second most stable conformer, $\mathbf{t T}$, has also two $\mathrm{H}$-bond interactions $\left(\mathrm{N}_{12}-\mathrm{H}_{15} \cdots \mathrm{O}_{6}=\right.$ and $\left.\mathrm{N}_{10}-\mathrm{H}_{13} \cdots \mathrm{N}_{3}\right)$, which, however, are weaker than those in the conformational ground state. In turn, the third and fourth conformers in order of energy ( $\mathbf{g}^{\prime} \mathbf{C}$ and $\mathbf{g}^{\prime} \mathbf{T}$, respectively) do not exhibit any H-bond or have only one weak $\mathrm{H}$-bond like interaction $\left(\mathrm{N}_{12}-\mathrm{H}_{15} \cdots \mathrm{N}_{3}\right)$.

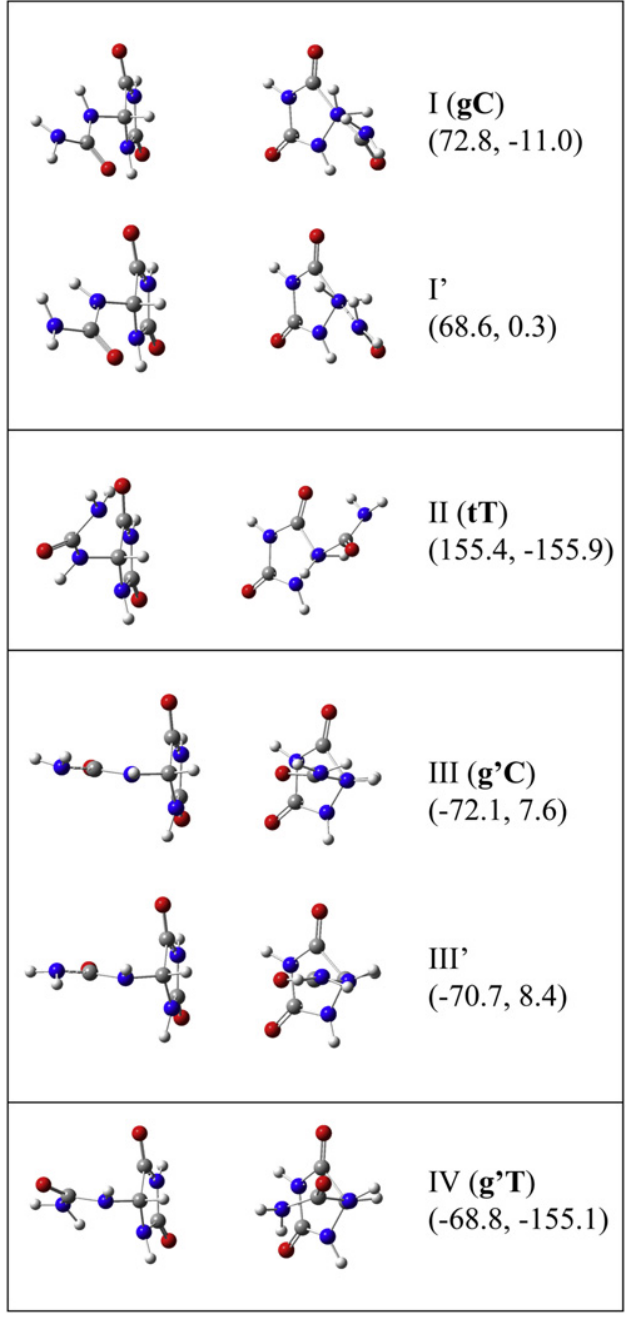

Figure 3. DFT/B3LYP/6-311 $++\mathrm{G}(\mathrm{d}, \mathrm{p})$ optimized geometries (two perspectives) of the six minima found on the potential energy surface of allantoin. In parentheses the values of the $\mathrm{N}_{3}-\mathrm{C}_{4}-\mathrm{N}_{10}-\mathrm{C}_{11}$ and $\mathrm{C}_{4}-\mathrm{N}_{10}-\mathrm{C}_{11}-\mathrm{O}_{14}$ dihedral angles (in degrees).

Table 1

DFT/B3LYP/6-311++G(d,p) calculated energies for the minima and transition state (TS) structures on the potential energy surface of allantoin and dipole moments for the relevant minima

\begin{tabular}{|c|c|c|c|c|}
\hline Minima/TS & Conformer & Energy/Hartree & $\Delta E / \mathrm{kJ} \mathrm{mol}^{-1}$ & $\mu /$ Debye \\
\hline I & gC & -600.9735194 & 0.00 & 3.57 \\
\hline $\mathrm{I}^{\prime}$ & & -600.9727559 & 2.00 & \\
\hline II & tT & -600.9693672 & 10.90 & 2.68 \\
\hline III & $\mathbf{g}^{\prime} \mathbf{C}$ & -600.9683094 & 13.68 & 6.06 \\
\hline $\mathrm{III}^{\prime}$ & & -600.9680536 & 14.35 & \\
\hline IV & $\mathbf{g}^{\prime} \mathbf{T}$ & -600.9667005 & 17.90 & 3.35 \\
\hline $\mathrm{TS}\left(\mathrm{I}^{\prime} \rightarrow \mathrm{I}\right)$ & & -600.9727542 & 0.0045 & \\
\hline $\mathrm{TS}\left(\mathrm{III}^{\prime} \rightarrow \mathrm{III}\right)$ & & -600.9678236 & 0.60 & \\
\hline $\mathrm{TS}(\mathrm{II} \rightarrow \mathrm{I})$ & & -600.9570749 & 32.27 & \\
\hline $\mathrm{TS}(\mathrm{III} \rightarrow \mathrm{I})$ & & -600.9626044 & 14.98 & \\
\hline $\mathrm{TS}(\mathrm{IV} \rightarrow \mathrm{II})$ & & -600.9597735 & 18.19 & \\
\hline $\mathrm{TS}(\mathrm{IV} \rightarrow \mathrm{III})$ & & -600.9532547 & 35.30 & \\
\hline
\end{tabular}

\subsection{Energy barriers for conformational interconversion}

As already mentioned, the barriers between the two $\mathbf{g C}$ minima and between the two $\mathbf{g}^{\prime} \mathbf{C}$ minima, measured from the bottom of the potential wells of the highest energy member of each pair, are very low (below $1 \mathrm{~kJ} \mathrm{~mol}^{-1}$; see Table 1 ). Hence, as referred to above, in practical terms each pair of minima corresponds to a single 

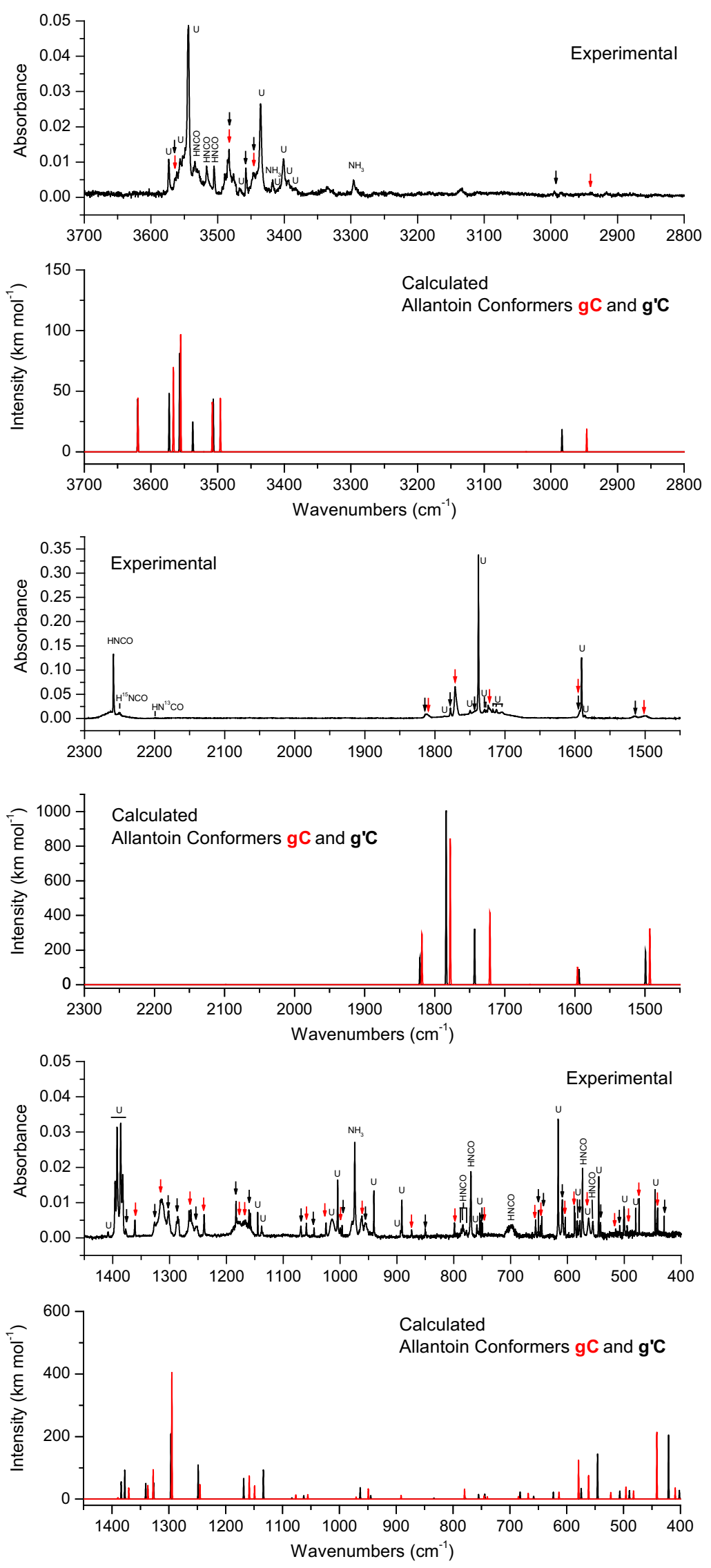
conformer. The barriers between the two $\mathrm{C}$ and between the two $\mathrm{T}$ conformers are $14.98\left(\mathbf{g}^{\prime} \mathbf{C} \rightarrow \mathbf{g C}\right)$ and $18.19 \mathrm{~kJ} \mathrm{~mol}^{-1}\left(\mathbf{g}^{\prime} \mathbf{T} \rightarrow \mathbf{t T}\right)$, respectively, whereas that between the two lowest energy forms, $\mathbf{t T}$ and $\mathbf{g C}$, is as large as $32.27 \mathrm{~kJ} \mathrm{~mol}^{-1}$. In relation with the matrix isolation experiments described in this paper, all these barriers may be considered high enough to preclude any isomerization to take place both during deposition and upon annealing of the matrices (conformational cooling ${ }^{35-37}$ ). This fact opened some perspectives regarding the possible observation of more than one conformer of allantoin in the matrix isolation infrared spectra if the compound could partially survive to the deposition procedure. On the other hand, using the Boltzmann statistics and the calculated relative energies of the conformers, their equilibrium populations could be estimated to be $98.3 / 1.2 / 0.4 / 0.1 \%\left(\mathbf{g C} / \mathbf{t T} / \mathbf{g}^{\prime} \mathbf{C} / \mathbf{g}^{\prime} \mathbf{T}\right)$ at room temperature and $90.2 / 5.9 / 2.9 / 1.0 \%$ at ca. $200{ }^{\circ} \mathrm{C}$ (approximate maximum temperature applied to the crystalline sample of allantoin to prepare the matrices). Hence, the possibility of experimental observation of both $\mathbf{t T}$ and $\mathbf{g}^{\prime} \mathbf{T}$ forms looked in fact very improbable, while that of observing $\mathbf{g}^{\prime} \mathbf{C}$ form could not be excluded a priori, since in the crystal allantoin molecules exist exclusively in this conformation. ${ }^{21}$ As it will be shown in detail below, in agreement with these expectations, we could found experimental evidence of both $\mathbf{g C}$ and $\mathbf{g}^{\prime} \mathbf{C}$ conformers of allantoin in the matrix isolation IR spectra, as minor species, together with its decomposition products.

\subsection{Allantoin isolated in argon matrix and identification of the products of its thermal decomposition}

The DSC experiments carried out on the compound placed in a hermetically sealed pan showed that allantoin starts to decompose simultaneously with the melting, at about $230^{\circ} \mathrm{C}$. These results show the thermal lability of the compound. However, under low pressure conditions, as those used in the matrix isolation experiments $\left(P=10^{-6} \mathrm{mbar}\right)$, it appeared possible that the compound could survive to decomposition, at least partially, and, as already mentioned, this was confirmed in practice.

Figure 4 shows the matrix isolation IR spectra obtained from heating allantoin and fast depositing the produced vapors onto the cold $(10 \mathrm{~K})$ substrate of the cryostat. The spectrum reveals very clearly the presence of urea and isocyanic acid as main products of thermal decomposition of allantoin. Besides these two substances, the matrix also indicates the presence of $\mathrm{NH}_{3}$ and a minor fraction of non-decomposed allantoin. Comparison of the experimental data with the calculated spectra for the different conformers of allantoin showed that in the matrix allantoin exists in two different conformational states: the conformer existing in the crystalline state $\left(\mathbf{g}^{\prime} \mathbf{C}\right)$ and the most stable one in gas phase $(\mathbf{g C})$. Analysis of the sample holder after the experiment revealed also the presence of a residue of carbon. Figure 5 shows the proposed set of processes resulting in the observed chemical species: (i) ring fragmentation of allantoin, yielding isocyanic acid and (ii) cleavage of the $\mathrm{C}_{4}-\mathrm{N}_{10}$ bond accompanied by migration of $\mathrm{H}_{17}$ resulting in formation of urea; carbon is formed as residue of (i) and (ii). The formed urea can then decompose partially to isocyanic acid and $\mathrm{NH}_{3}$. Simultaneously, a minor amount of allantoin molecules that survived to heating land on the cold surface of the cryostat in the conformation existing in the crystalline sample $\left(\mathbf{g}^{\prime} \mathbf{C}\right)$ or, after conformational isomerization in the gas phase along deposition, as the gas phase most stable conformer $\mathbf{g C}$.

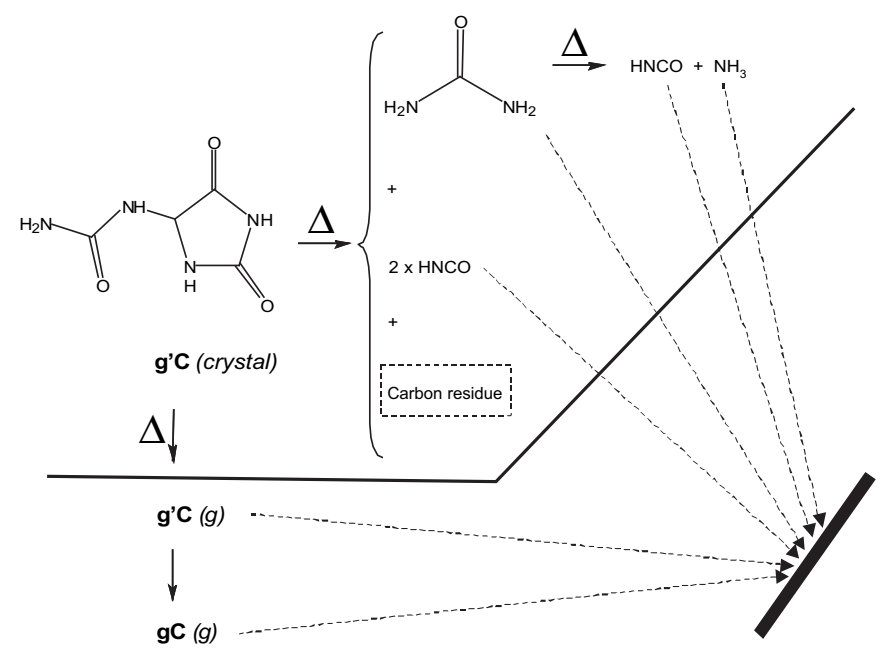

Figure 5. Schematic representation of the observed thermal decomposition processes and conformational isomerization of allantoin.

The infrared spectrum of matrix isolated urea is well known. A comprehensive study of urea and several of its isotopomers in argon matrix was reported by Dobrowolski et al. ${ }^{38} \mathrm{~A}$ one-to-one correspondence between the bands reported by Dobrowolski et al. ${ }^{38}$ and those assigned to urea in the spectrum resulting from allantoin decomposition could be established (Table 2 ), testifying unequivocally that urea has been produced and could be efficiently isolated in the low temperature matrix. Decomposition of allantoin into urea was already reported on heating the compound in the presence of water, ${ }^{39}$ in a process, which also gives rise to allanturic acid $\left(\mathrm{C}_{3} \mathrm{H}_{4} \mathrm{O}_{3} \mathrm{~N}_{2}\right)$. The latter molecule, however, was not observed in our experiments, since for its production a water molecule is required, which is unavailable under the present experimental conditions.

The observed $\mathrm{NH}_{3}$ results from decomposition of urea, accompanied by formation of isocyanic acid. This is a well documented process $^{40,41}$ that has recently been shown to be the most favorable decomposition pathway for an isolated urea molecule. ${ }^{41}$ The presence of $\mathrm{NH}_{3}$ in the studied argon matrix was doubtlessly established by observation of the characteristic band at $974 \mathrm{~cm}^{-1}$ due to the umbrella mode, ${ }^{42-44}$ and further confirmed by observation of a few additional bands that were previously found ${ }^{44}$ to be good indicators of $\mathrm{NH}_{3}$ in argon matrix.

Isocyanic acid results from two different processes: it is produced directly from allantoin and also from decomposition of the previously formed urea, as described above (see also Fig. 5). Isocyanic acid has been studied extensively in low temperature inert matrices and its infrared spectrum in argon matrix is then well known. ${ }^{16,45-48}$ As shown in Table 2, the infrared signature of isocyanic acid is easily identifiable in the obtained matrix isolation spectra. Indeed, not just the very characteristic band at $2259 \mathrm{~cm}^{-1}$, assigned to the $v \mathrm{NCO}$ asymmetric stretching vibration, could be observed, but all other previously reported IR bands of matrix isolated isocyanic acid, including those reflecting the fact that the HNCO molecule isolated in argon can rotate almost freely along its $a$ axis $^{45,48}$ and, in the case of the $v \mathrm{NCO}$ asymmetric stretching vibration, even those bands originated in minor isotopomers of the compound ( $\mathrm{HN}^{13} \mathrm{CO}$ and $\left.\mathrm{H}^{15} \mathrm{NCO}\right)$; see Figure 4 and Table 2.

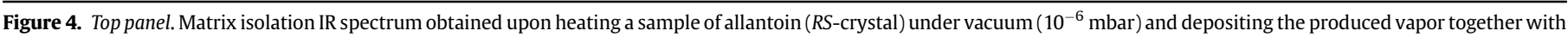

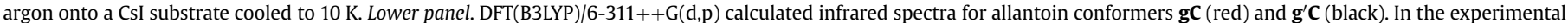

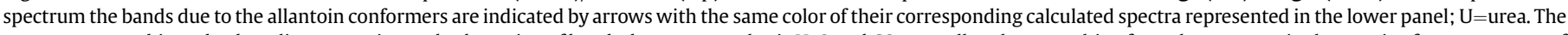

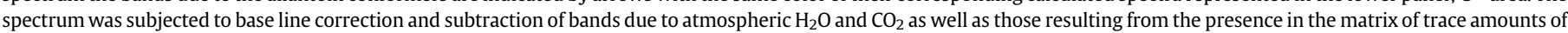

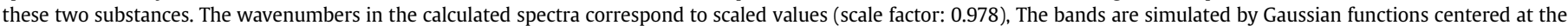
absorption wavenumber and area equal to the calculated intensity. Three different spectral regions are shown: $3700-2800 \mathrm{~cm}^{-1}, 2300-1450 \mathrm{~cm}^{-1}$, and $1450-400 \mathrm{~cm}^{-1}$. 
Table 2

Infrared spectrum obtained upon deposition of a sample of allantoin as described in the Experimental section

\begin{tabular}{|c|c|c|c|c|c|c|}
\hline \multicolumn{3}{|l|}{ Experimental $^{\mathrm{a}}$} & \multicolumn{2}{|c|}{ Calculated (allantoin) ${ }^{\mathrm{b}}$} & \multicolumn{2}{|c|}{ Assignment } \\
\hline This work & Others & Ref. & gC & $\mathbf{g}^{\prime} \mathbf{C}$ & Species $^{c}$ & Mode $^{d}$ \\
\hline 3574 & 3573.6 & 38 & & & Urea & $v \mathrm{NH}_{2}$ as. \\
\hline 3563 & & & & 3620 & & $v \mathrm{NH}_{2}$ as. \\
\hline 3560 & & & 3619 & & & $v \mathrm{NH}_{2}$ as. \\
\hline 3556 & 3556.4 & 38 & & & Urea & \\
\hline 3552 & 3552.3 & 38 & & & & $v \mathrm{NH}_{2}$ as. \\
\hline 3550 & 3550.4 & 38 & & & & \\
\hline 3545 & 3544.6 & 38 & & & Urea & $v \mathrm{NH}_{2}$ as. \\
\hline 3544 & 3543.9 & 38 & & & & \\
\hline 3536 & e & 45 & & & HNCO & \\
\hline 3534 & e & 45 & & & & $\vee \mathrm{NH} 1 \leftarrow 0$ \\
\hline 3529 & e & 45 & & & & \\
\hline 3516 & 3516.8 & 45 & & & HNCO & $\vee \mathrm{NH} 0 \leftarrow 0$ \\
\hline 3505 & 3505.7 & 45 & & & & \\
\hline 3493, 3489 & & & & 3572 & & vNH (ring) \\
\hline 3485 & & & 3566 & & & $v \mathrm{NH}$ (ring) \\
\hline 3483,3481 & & & 3555 & & & $v \mathrm{NH}$ (ring) \\
\hline 3476,3473 & & & & 3557 & & $v \mathrm{NH}$ (ring) \\
\hline 3463 & 3463.0 & 38 & & & Urea & $v \mathrm{NH}_{2} \mathrm{~s}$ \\
\hline 3457 & & & & 3537 & & vNH (imide) \\
\hline & & & 3507 & & & $v \mathrm{NH}_{2}$ sym. \\
\hline 3441 & & & & 3506 & & $v \mathrm{NH}_{2} \mathrm{~s}$ \\
\hline & & & 3495 & & & vNH (imide) \\
\hline 3440 & 3439.9 & 38 & & & Urea & $v \mathrm{NH}_{2} \mathrm{~s}$ \\
\hline 3435 & 3436.2 & 38 & & & Urea & $v \mathrm{NH}_{2} \mathrm{~s}$. \\
\hline 3433 & 3433.1 & 38 & & & & \\
\hline 3417 & 3417.0 & 44 & & & $\mathrm{NH}_{3}$ & $v \mathrm{NH}_{3}$ as. \\
\hline 3409 & 3411.8 & 38 & & & Urea & \\
\hline 3401 & 3402.9 & 38 & & & & \\
\hline 3399 & 3401.8 & 38 & & & & $v \mathrm{NH}_{2} \mathrm{~s}$. \\
\hline 3395 & 3399.2 & 38 & & & & \\
\hline 3383 & 3382.9 & 38 & & & & \\
\hline 3336 & & & & & $?$ & \\
\hline 3296 & 3296.8 & 44 & & & $\mathrm{NH}_{3}$ & $v \mathrm{NH}_{3} \mathrm{~s}$. \\
\hline 3135 & & & & & $?$ & \\
\hline 2995, 2985 & & & & 2983 & & $v \mathrm{CH}$ \\
\hline 2941 & & & 2945 & & & $v \mathrm{CH}$ \\
\hline 2259 & 2259.0 & 45 & & & HNCO & $v \mathrm{NCO}$ as. $0 \leftarrow 0$ \\
\hline 2250 & 2250.8 & 45 & & & $\mathrm{H}^{15} \mathrm{NCO}$ & $v^{15} \mathrm{NCO}$ as. \\
\hline 2199 & 2199.0 & 45 & & & $\mathrm{HN}^{13} \mathrm{CO}$ & $v \mathrm{~N}^{13} \mathrm{CO}$ as. \\
\hline 1813 & & & & 1820 & & $v C=0$ (ring) \\
\hline 1812 & & & 1817 & & & $v C=0$ (ring) \\
\hline 1786 & 1785.6 & 38 & & & Urea & $v \mathrm{C}=\mathrm{O}$ \\
\hline 1778 & & & & 1782 & & $v \mathrm{C}=\mathrm{O}$ (ring) \\
\hline 1771 & & & 1777 & & & $v \mathrm{C}=\mathrm{O}$ (ring) \\
\hline 1750 & 1752.1 & 38 & & & Urea & $v C=0$ \\
\hline 1742 & & & & 1742 & & $v \mathrm{C}=\mathrm{O}$ (amide) \\
\hline \multirow[t]{2}{*}{1737} & 1737.9 & 38 & & & Urea & \\
\hline & 1736.5 & 38 & & & & $v C=0$ \\
\hline 1729 & 1728.7 & 38 & & & & \\
\hline 1724,1722 & & & 1721 & & & $v \mathrm{C}=\mathrm{O}$ (amide) \\
\hline 1717 & 1717.6 & 38 & & & & \\
\hline 1712 & 1712.0 & 38 & & & Urea & $v C=0$ \\
\hline \multirow[t]{2}{*}{1704} & 1704.9 & 38 & & & & \\
\hline & & & 1595 & & & $\delta \mathrm{NH}_{2}$ \\
\hline \multirow[t]{2}{*}{1592} & & & & 1593 & & $\delta \mathrm{NH}_{2}$ \\
\hline & 1593.1 & 38 & & & Urea & $\delta \mathrm{NH}_{2}$ as. \\
\hline 1591 & 1590.8 & 38 & & & Urea & $\delta \mathrm{NH}_{2}$ as. \\
\hline 1586 & 1587.0 & 38 & & & Urea & $\delta \mathrm{NH}_{2} \mathrm{~s}$. \\
\hline 1515 & & & & 1498 & & $\delta \mathrm{NH}$ (imide) \\
\hline 1500 & & & 1492 & & & $\delta \mathrm{NH}$ (imide) \\
\hline 1408 & 1408.3 & 38 & & & Urea & \\
\hline 1396 & 1396.0 & 38 & & & & \\
\hline \multirow[t]{2}{*}{1392} & 1392.3 & 38 & & & & $v \mathrm{CN}$ as. \\
\hline & 1391.1 & 38 & & & & \\
\hline 1386 & 1386.2 & 38 & & & & \\
\hline 1382 & 1382.7 & 38 & & & & \\
\hline 1377 & & & & 1377 & & $v$ ring \\
\hline 1361 & & & 1370 & & & $v$ ring \\
\hline 1326 & & & & 1340 & & $\gamma \mathrm{CH}$ \\
\hline 1316 & & & 1336 & & & $\gamma \mathrm{CH}$ \\
\hline $1314,1313,1311$ & & & 1327 & & & $\delta \mathrm{NH}$ (ring) \\
\hline 1301 & & & & 1327 & & $\delta \mathrm{NH}$ (ring) \\
\hline $1287,1285,1284$ & & & & 1296 & & $v \mathrm{C}_{11}-\mathrm{N}_{12}$ \\
\hline $1265,1264,1262$ & & & 1294 & & & $v \mathrm{C}_{11}-\mathrm{N}_{12}$ \\
\hline
\end{tabular}


Table 2 (continued)

\begin{tabular}{|c|c|c|c|c|c|c|}
\hline \multicolumn{3}{|c|}{ Experimental $^{\mathrm{a}}$} & \multicolumn{2}{|c|}{ Calculated (allantoin) $^{\mathrm{b}}$} & \multicolumn{2}{|c|}{ Assignment } \\
\hline This work & Others & Ref. & gC & $\mathbf{g}^{\prime} \mathbf{C}$ & Species $^{c}$ & Mode $^{\mathrm{d}}$ \\
\hline 1252 & & & & 1248 & & w R-U \\
\hline 1239 & & & 1244 & & & w R-U \\
\hline 1182 & & & & 1168 & & $v$ ring \\
\hline 1178 & & & 1158 & & & $v$ ring \\
\hline 1167 & & & 1149 & & & $v \mathrm{C}_{4}-\mathrm{N}_{10}$ \\
\hline 1161,1158 & & & & 1133 & & $v \mathrm{C}_{4}-\mathrm{N}_{10}$ \\
\hline 1145 & 1145.0 & 38 & & & Urea & $\gamma \mathrm{NH}_{2} \mathrm{~s}$. \\
\hline 1138 & 1138.2 & 38 & & & & \\
\hline 1068 & & & & 1083 & & $\mathrm{wNH}_{2}$ \\
\hline 1058 & & & 1076 & & & $\mathrm{wNH}_{2}$ \\
\hline 1045 & & & & 1062 & & $v$ ring \\
\hline 1024 & & & 1055 & & & $v$ ring \\
\hline 1012 & 1008.7 & 38 & & & Urea & $\gamma \mathrm{NH}_{2}$ as. \\
\hline 1004 & 1004.3 & 38 & & & & \\
\hline 1000 & & & 970 & & & $v \mathrm{C}_{11}-\mathrm{N}_{10}$ \\
\hline 996 & & & & 963 & & umbrella \\
\hline 978,974 & 974.3 & 44 & & & $\mathrm{NH}_{3}$ & $v$ ring \\
\hline 962 & & & 949 & & & \\
\hline 955 & & & & 945 & & $v \mathrm{C}_{11}-\mathrm{N}_{10}$ \\
\hline 940 & 940.8 & 38 & & & Urea & $v \mathrm{CN} s$. \\
\hline 893,891 & 891.4 & 38 & & & & \\
\hline 874 & & & 891 & & & $v$ ring \\
\hline 850 & & & & 833 & & $\gamma$ R-U \\
\hline 799 & & & 780 & & & $\gamma \mathrm{C}=\mathrm{O}$ (amide) \\
\hline 785 & 821.6 & 45 & & & HNCO & $\delta$ HNC $1 \leftarrow 0$ \\
\hline 783 & 819.1 & 45 & & & & \\
\hline 778 & 790.7 & 45 & & & HNCO & $\delta$ HNC $1 \leftarrow 1$ \\
\hline 771 & 771.0 & 38 & & & Urea & $\gamma C=0$ \\
\hline 770 & 769.8 & 45 & & & HNCO & $\delta \mathrm{HNC} 0 \leftarrow 0$ \\
\hline 759 & 759.3 & 38 & & & Urea & $\gamma C=0$ \\
\hline 754 & 754.2 & 38 & & & & \\
\hline 751 & & & & 744 & & $\gamma \mathrm{C}=\mathrm{O}$ (ring) \\
\hline 750 & & & 740 & & & $\gamma \mathrm{C}=\mathrm{O}$ (ring) \\
\hline 697 & 697.0 & 45 & & & HNCO & $\gamma \mathrm{NCO} 1 \leftarrow 0$ \\
\hline 656 & & & 684 & & & $\delta \mathrm{C}=\mathrm{O}$ (amide) \\
\hline 651 & & & & 682 & & $\delta$ ring \\
\hline 647 & & & 667 & & & $\gamma \mathrm{C}=\mathrm{O}$ (ring) \\
\hline \multirow[t]{2}{*}{645} & & & & 658 & & $\gamma \mathrm{C}=\mathrm{O}$ (ring) \\
\hline & 635.9 & 38 & & & Urea & $\delta C=0$ \\
\hline 616 & 616.4 & 38 & & & & \\
\hline 609 & & & & 623 & & $\delta$ ring \\
\hline 604 & & & 613 & & & $\delta$ ring \\
\hline 587 & & & 579 & & & $\gamma \mathrm{NH}$ (ring) \\
\hline 582 & 582.4 & 38 & & & Urea & $\tau \mathrm{NH}_{2}$ as. \\
\hline 578 & & & & 574 & & $\gamma \mathrm{NH}$ (ring) \\
\hline 574 & 573.7 & 45 & & & HNCO & $\delta N C O \quad 0 \leftarrow 0$ \\
\hline \multirow[t]{2}{*}{562} & & & 561 & & & $\delta$ ring \\
\hline & 550.6 & 38 & & & Urea & $\tau \mathrm{NH}_{2} \mathrm{~S}$ \\
\hline 555 & 554.5 & 45 & & & HNCO & $\delta N C O \quad 1 \leftarrow 1$ \\
\hline 545 & 544.8 & 38 & & & Urea & $\tau \mathrm{NH}_{2} \mathrm{~s}$ \\
\hline 541 & & & & 546 & & $\gamma \mathrm{NH}$ (ring) \\
\hline 515 & & & 522 & & & $\gamma \mathrm{NH}$ (ring) \\
\hline 508 & & & & 506 & & $\gamma \mathrm{NH}_{2}$ \\
\hline 500 & 500.5 & 38 & & & Urea & $?$ \\
\hline \multirow[t]{2}{*}{495} & & & 496 & & & $\gamma \mathrm{NH}_{2}$ \\
\hline & 483.7 & 38 & & & Urea & $\delta \mathrm{NCN}$ \\
\hline 479 & 480.0 & 38 & & & & \\
\hline 473 & & & 482 & & & $\gamma \mathrm{NH}$ (ring) \\
\hline 445 & 445.1 & 38 & & & Urea & $\mathrm{wNH}_{2} \mathrm{~s}$. \\
\hline 442,441 & & 441 & & & & $\gamma \mathrm{NH}$ (imide) \\
\hline 429 & & & & 421 & & $\gamma \mathrm{NH}$ (imide) \\
\hline
\end{tabular}

a Wavenumbers in $\mathrm{cm}^{-1}$

b Scaled wavenumbers.

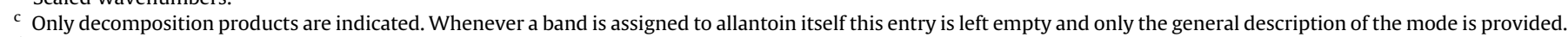

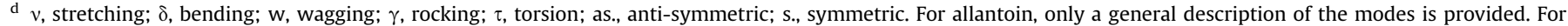
a detailed vibrational analysis and full mode characterization, see Tables S3 and S4-Supplementary data.

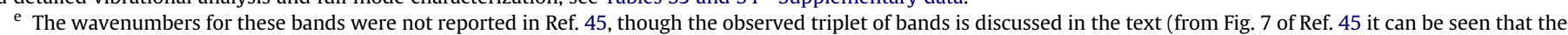
triplet of bands stays roughly between 3540 and $3525 \mathrm{~cm}^{-1}$, as observed in the present study).

Identification of allantoin as a minor species in the matrix isolation spectra was made promptly by analysis of the carbonyl stretching region (1850-1700 $\mathrm{cm}^{-1}$; see Fig. $\left.4 \mathrm{~b}\right)$, since the bands observed above $1750 \mathrm{~cm}^{-1}$ could not be ascribed to any of the expected products of decomposition of allantoin whereas they fit nicely the calculated spectra for allantoin in this spectral region. In particular, comparison of the experimental spectrum with the DFT calculated spectra for the different minima of allantoin revealed that both conformers $\mathbf{g C}$ and $\mathbf{g}^{\prime} \mathbf{C}$ contribute to the experimental spectrum. In the carbonyl stretching region, the three expected IR 
bands due conformer $\mathbf{g C}$ were predicted at 1817, 1777, and $1720 \mathrm{~cm}^{-1}$ and observed at 1812,1771 , and $1724 \mathrm{~cm}^{-1}$, respectively, while those due to conformer $\mathbf{g}^{\prime} \mathbf{C}$ were calculated to occur at 1820 , 1782 , and $1742 \mathrm{~cm}^{-1}$ and observed at 1813,1778 , and $1742 \mathrm{~cm}^{-1}$. As shown in Figure 4 and Table 2, besides the bands observed in the carbonyl stretching region, many other bands due to allantoin $\mathbf{g C}$ and $\mathbf{g}^{\prime} \mathbf{C}$ conformers could be identified in the experimental matrix isolation spectrum. While some of the proposed assignments must be considered as tentative, the general fitting between the predicted infrared spectra for these conformers (see Tables S2-S4 in the Supplementary data for full theoretical IR data) and their experimentally observed vibrational signature is very good and allows for the unequivocal identification of these species. On the other hand, in consonance with our expectations based on the theoretical conformational analysis no evidence of conformers $\mathbf{t T}$ and $\mathbf{g}^{\prime} \mathbf{T}$ was found experimentally. The comparison of the predicted spectra for all four conformers of allantoin can be made based on Table S5 (Supplementary data). A selected spectral region is shown in Figure 6, where the experimental spectrum is compared with
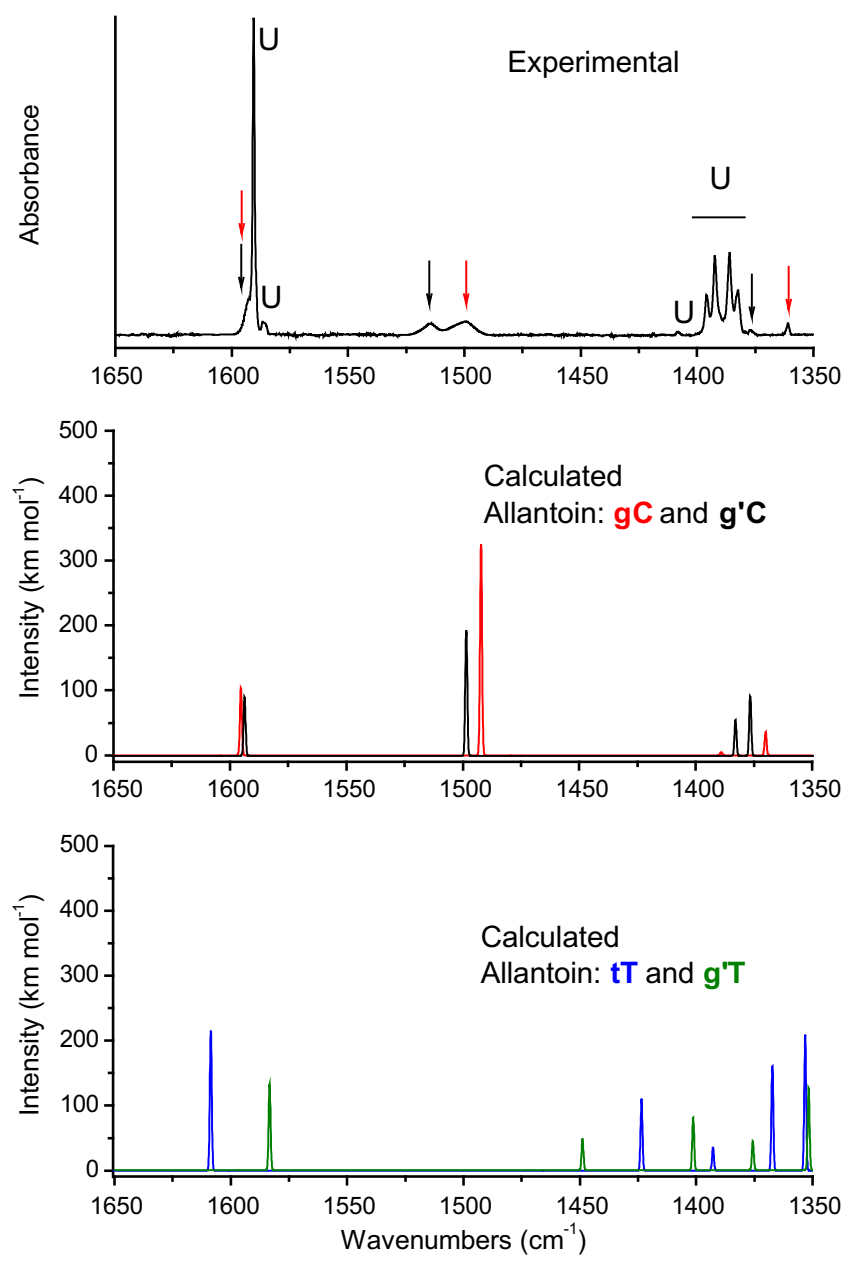

Figure 6. Top panel. $1650-1350 \mathrm{~cm}^{-1}$ region of the matrix isolation IR spectrum obtained upon heating a sample of allantoin (RS-crystal) under vacuum $\left(10^{-6} \mathrm{mbar}\right)$ and depositing the produced vapor together with argon onto a CsI substrate cooled to $10 \mathrm{~K}$. Mid and lower panels. DFT(B3LYP)/6-311++G(d,p) calculated infrared spectra for allantoin conformers $\mathbf{g C}$ (red), $\mathbf{g}^{\prime} \mathbf{C}$ (black), $\mathbf{t T}$ (blue), and $\mathbf{g}^{\prime} \mathbf{T}$ (green). In the experimental spectrum the bands due to the allantoin conformers are indicated by arrows with the same color of their corresponding calculated spectra represented in the lower panels; $\mathrm{U}=$ urea. The spectrum was subjected to base line correction and subtraction of bands due to atmospheric $\mathrm{H}_{2} \mathrm{O}$ as well as those resulting from the presence in the matrix of trace amounts of this substance. The wavenumbers in the calculated spectra correspond to scaled values (scale factor: 0.978), The bands are simulated by Gaussian functions centered at the absorption wavenumber and area equal to the calculated intensity. those of the different conformers. From this figure it is clear that only conformers $\mathbf{g C}$ and $\mathbf{g}^{\prime} \mathbf{C}$ contribute to the spectrum of the obtained matrix, whereas $\mathbf{t} \mathbf{T}$ and $\mathbf{g}^{\prime} \mathbf{T}$ are absent, e.g., the intense bands of the $\mathbf{t T}$ conformer predicted to occur at 1608,1423 , and $1353 \mathrm{~cm}^{-1}$ have no experimental counterpart, as well as those predicted for $\mathbf{g}^{\prime} \mathbf{T}$ at $1583,1449,1401$, and $1352 \mathrm{~cm}^{-1}$. Other intense bands calculated for these two conformers expected to appear in sparsely populated spectral regions that could not be observed in the experimental spectrum, thus further supporting our conclusion, are those predicted at $1119 \mathrm{~cm}^{-1}(\mathbf{t T})$ and 1140 and $1101 \mathrm{~cm}^{-1}$ (g'T) (see Fig. 4 and Table S5).

\subsection{Infrared spectrum of crystalline allantoin at room temperature}

The infrared spectrum of crystalline allantoin had never been studied in detail before. This spectrum is shown in Figure 7. Comparison of this spectrum with that predicted for the relevant isolated monomer $\left(\mathbf{g}^{\prime} \mathbf{C}\right)$ as well as the spectrum of urea ${ }^{49}$ allowed to undertake its assignment, as shown in Table 3.

When compared with the spectrum of the isolated monomer, the spectrum of the crystal exhibits the expected ${ }^{50-53}$ pronounced

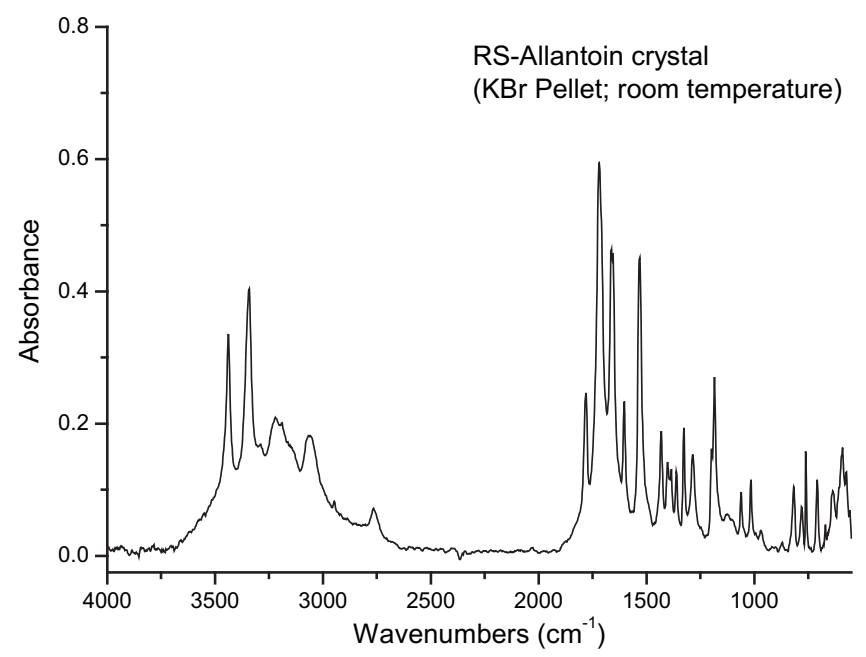

Figure 7. Room temperature infrared spectrum of $R S$-allantoin crystal in $\mathrm{KBr}$ pellet.

Table 3

Infrared observed wavenumbers $\left(\mathrm{cm}^{-1}\right)$ and assignment for crystalline allantoin (RS-crystal) in $\mathrm{KBr}$ pellet at room temperature ${ }^{\mathrm{a}}$

\begin{tabular}{llcl}
\hline Wavenumber & Assignment & Wavenumber & Assignment \\
\hline 3438 & $v \mathrm{NH}_{2}$ as. & 1326 & $v \mathrm{C}_{11}-\mathrm{N}_{12}$ \\
3343 & $v \mathrm{NH}$ (ring) & 1285 & $\mathrm{w} \mathrm{R}-\mathrm{U}$ \\
3289 & & 1198 & $v$ ring \\
3221 & & 1185 & $v \mathrm{C}_{4}-\mathrm{N}_{10}$ \\
3191 & & 1125,1101 & $\mathrm{wNH}_{2}$ \\
3148 & $v \mathrm{NH}$ (imide) & 1061 & $v$ ring \\
3066 & $v \mathrm{NH}_{2} \mathrm{~s}$. & 1016 & $v$ ring \\
2948 & $v \mathrm{CH}$ & 969 & $\gamma \mathrm{R}-\mathrm{U}$ \\
2766 & $1719+1061$ & 870 & $v \mathrm{C}_{11}-\mathrm{N}_{10}$ \\
1781 & $v \mathrm{C}=\mathrm{O}$ (ring) & 817 & $v$ ring \\
1719 & $v \mathrm{C}=\mathrm{O}$ (ring) & 780 & $\gamma \mathrm{C}=\mathrm{O}$ (amide) \\
1663,1666 & $v \mathrm{C}=\mathrm{O}$ (amide) & 761 & $\gamma \mathrm{C}=\mathrm{O}$ (ring) \\
1603 & $\delta \mathrm{NH} \mathrm{H}_{2}$ & 708 & $\delta$ ring \\
1532 & $\delta \mathrm{NH}$ (imide) & 670 & $\gamma \mathrm{C}=\mathrm{O}$ (ring) \\
1432 & $\delta \mathrm{NH}$ (ring) & 636 & $\delta$ ring \\
1402 & $v$ ring & 591 & $\gamma \mathrm{NH}$ (ring) \\
1385 & $\gamma \mathrm{CH}$ & 574 & $\gamma \mathrm{NH}$ (ring) \\
1361 & $\delta \mathrm{NH}$ (ring) & 557 & $\gamma \mathrm{NH} \mathrm{H}_{2}$ \\
\hline
\end{tabular}

${ }^{a} v$, stretching; $\delta$, bending; w, wagging; $\gamma$, rocking; as., anti-symmetric; s., symmetric; R-U means movements of the ring (R) in relation to the ureidyl moiety (U). See Figure 1 for atom numbering. 
down shifts of the stretching bands associated with the groups taking part in intermolecular $\mathrm{H}$-bonding (e.g., $v \mathrm{NH}_{2}, v \mathrm{NH}$, and $\nu \mathrm{C}=\mathrm{O}$ modes; see Tables 2 and 3 ) and up shifts of the corresponding bending modes $\left(\delta \mathrm{NH}, \gamma \mathrm{NH}, \gamma \mathrm{NH}_{2}, \gamma \mathrm{C}=\mathrm{O}\right)$.

Most of the bands associated with the ureidyl fragment in crystalline allantoin were found at very similar positions when compared with the analogous vibrations in urea, ${ }^{49}$ i.e., $v \mathrm{NH}_{2}$ between 3450 and $3050 \mathrm{~cm}^{-1}$ (as a broad complex band), $v \mathrm{C}=\mathrm{O}$ at $1666 / 1663 \mathrm{~cm}^{-1}\left(1686 \mathrm{~cm}^{-1}\right.$ in urea), $\delta \mathrm{NH}_{2}$ at 1603 (1631 and $1606 \mathrm{~cm}^{-1}$ in urea), $\mathrm{wNH}_{2}$ at $1125 / 1101 \mathrm{~cm}^{-1}$ (urea: $1153 \mathrm{~cm}^{-1}$ ) and $\gamma \mathrm{C}=0$ at $780 \mathrm{~cm}^{-1}$ (urea: $789 \mathrm{~cm}^{-1}$ ), which points to a similar environment of the ureidyl fragment in allantoin crystal compared to crystalline urea. On the other hand, the $v \mathrm{CN}$ bands are observed in allantoin at somewhat lower wavenumbers (1326 and $870 \mathrm{~cm}^{-1}$ ) than in urea ( 1468 and $1005 \mathrm{~cm}^{-149}$ ), as it could be expected taking into account the more extensive coupling with other skeletal vibrations in the studied compound.

\section{Conclusions}

The detailed investigation of the DFT(B3LYP)/6-311++G(d,p) potential energy surface of allantoin revealed the existence of four conformers ( $\mathbf{g C}, \mathbf{t T}, \mathbf{g}^{\prime} \mathbf{C}$, and $\mathbf{g}^{\prime} \mathbf{T}$ ). The $\mathbf{g C}$ form was found to be the most stable conformer in gas phase, contrarily to what was observed in the crystalline state $\left(R S\right.$-allantoin $\left.{ }^{21}\right)$, where the $\mathbf{g}^{\prime} \mathbf{C}$ conformer was found to be the constituting monomeric unit. This fact stresses the importance of intermolecular $\mathrm{H}$-bonding in determining the structure of the crystal.

Upon sublimation under vacuum $\left(10^{-6} \mathrm{mbar}\right)$, the compound was found to undergo extensive decomposition to urea, isocyanic acid, $\mathrm{NH}_{3}$, and carbon. The identification of the decomposition products was successfully made by using matrix isolation infrared spectroscopy, with the spectroscopic fingerprint of all the reaction products clearly depicted in the matrix isolation infrared spectrum. In consonance with the theoretical predictions, in particular the relative energies of the different conformers of allantoin and the energy barriers separating these forms, allantoin molecules surviving thermal decomposition were found to undergo conformational isomerization in the gaseous phase and be present in the cryogenic argon matrix in both the $\mathbf{g} \mathbf{C}$ and $\mathbf{g}^{\prime} \mathbf{C}$ conformations.

The solid state room temperature infrared spectrum of allantoin was also investigated and fully assigned.

\section{Acknowledgements}

The authors gratefully acknowledge Prof. Mustafa Korkmaz, Hacettepe University, Ankara, for providing us with a sample of allantoin and Profs. Ermelinda Eusébio and Teresa Estronca for making available the instruments for the DSC studies. This study was run under the Portuguese Science Foundation (FCT-Fundação para a Ciência e Tecnologia) Project PTDC/QUI/71203/2006.

\section{Supplementary data}

Supplementary data associated with this article can be found on online version, at doi:10.1016/j.tet.2009.09.088.

\section{References and notes}

1. Mendel, L. B.; Dankin, H. D. J. Biol. Chem. 1910, 153.

2. Christman, A. A. J. Biol. Chem. 1926, 173.

3. Robinson, W. J. Parasitol. 1935, 21, 354.

4. Shestopalov, A. V.; Shkurat, T. P.; Mikashinovich, Z. I.; Kryzhanovskaia, I. O.; Bogacheva, M. A.; Lomteva, S. V.; Prokof'ev, V. P.; Gus'kov, E. P. Izv. Akad. Nauk.: Ser. Biol. 2006, 5, 541.
5. Simoyi, M. F.; Falkenstein, E.; Van Dyke, K.; Blemings, K. P.; Klandorf, H. Comp. Biochem. Physiol. B: Biochem. Mol. Biol. 2003, 135, 325.

6. Fujihara, S.; Yamaguchi, M. Phytochemistry 1978, 17, 1239.

7. Young, K. G.; Wentworth, H. P.; Hawkins, W. W. J. Pharmacol. Exp. Ther. 1944, 81, 1.

8. Fujiwara, S.; Noguchi, T. Biochem. J. 1995, 312, 315.

9. Thornfeldt, C. Dermat. Surg. 2005, 31, 873.

10. Disalvo, R. M. Chem. Manufact. Cosmetics 2002, 3, 29.

11. Eggensperger, H. Multiaktive Wirkstoffe für Kosmetika 1995, 9.

12. Stark, G. R. Biochemistry 1965, 4, 2363.

13. Stark, G. R. Biochemistry 1965, 4, 1030 .

14. Haley, R. J.; Ward, D. M. Am. J. Kidney Dis. 1986, 8, 115.

15. E Roxborough, H.; Young, I. S. Med. Hypotheses 1995, 45, 125.

16. Gómez-Zavaglia, A.; Reva, I. D.; Frija, L.; Cristiano, M. L.; Fausto, R. J. Photochem. Photobiol. A: Chem. 2006, 179, 243.

17. Caussé, E.; Pradelles, A.; Dirat, B.; Negre-Salvayre, A.; Salvayre, R.; Couderc, F. Electrophoresis 2007, 28, 381

18. Jin, P.; Ma, J.; Wu, X.; Zou, D.; Sun, C.; Hu, X. J. Pharm. Biomed. Anal. 2009, 50, 293.

19. Kim, K. M.; Henderson, G. N.; Frye, R. F.; Galloway, C. D.; Brown, N. J.; Segal, M. S.; Imaram, W.; Johnson, R. J. J. Chromatogr., B 2009, 877, 65.

20. Lagendijk, J.; Ubbink, J. B.; Vermaak, W. J. J. Chromatogr. Sci. 1995, 33, 186.

21. Mootz, D. Acta Crystallogr. 1965, 19, 726.

22. Kahn, K.; Tipton, P. A. Bioorg. Chem. 2000, 27, 62.

23. Kahn, K. Kinetic and Mechanistic Characterization of the Urate Oxidade reaction, Ph.D. Thesis, University of Missouri, Columbia, USA, 1998.

24. Sabbahm, R.; Wu, A. X.; Chickos, J. S.; Leitão, M. L. P.; Roux, N. V.; Torres, L. A. Thermochim. Acta 1995, 331, 93.

25. Frisch, M. J.; Trucks, G. W.; Schlegel, H. B.; Scuseria, G. E.; Robb, M. A. Cheeseman, J. R.; Montgomery, J. A., Jr.; Vreven, T.; Kudin, K. N.; Burant, J. C.; Millam, J. M.; Iyengar, S. S.; Tomasi, J.; Barone, V.; Mennucci, B.; Cossi, M.; Scalmani, G.; Rega, N.; Petersson, G. A.; Nakatsuji, H.; Hada, M.; Ehara, M.; Toyota, K.; Fukuda, R.; Hasegawa, J.; Ishida, M.; Nakajima, T.; Honda, Y.; Kitao, O.; Nakai, H.; Klene, M.; Li, X.; Knox, J. E.; Hratchian, H. P.; Cross, J. B.; Adamo, C.; Jaramillo, J.; Gomperts, R.; Stratmann, R. E.; Yazyev, O.; Austin, A. J.; Cammi, R.; Pomelli, C.; Ochterski, J. W.; Ayala, P. Y.; Morokuma, K.; Voth, G. A.; Salvador, P. Dannenberg, J. J.; Zakrzewski, V. G.; Dapprich, S.; Daniels, A. D.; Strain, M. C.; Farkas, O.; Malick, D. K.; Rabuck, A. D.; Raghavachari, K.; Foresman, J. B.; Ortiz, J. V.; Cui, O.; Baboul, A. G.; Clifford, S.; Cioslowski, J.; Stefanov, B. B.; Liu, G.; Liashenko, A.; Piskorz, P.; Komaromi, I.; Martin, R. L.; Fox, D. J.; Keith, T.; AlLaham, M. A.; Peng, C. Y.; Nanayakkara, A.; Challacombe, M.; Gill, P. M. W.; Johnson, B.; Chen, W.; Wong, M. W.; González, C.; Pople, J. A. GAUSSIAN 03 Revision B. 04; Gaussian: Pittsburgh, PA, 2003.

26. McLean, A. D.; Chandler, G. S. J. Chem. Phys. 1980, 72, 5639.

27. Krishnan, R.; Binkley, J. S.; Seeger, R.; Pople, J. A. J. Chem. Phys. 1980, 72, 650.

28. Becke, A. D. Phys. Rev. A 1988, 38, 3098

29. Lee, C.; Yang, W.; Parr, R. G. Phys. Rev. B 1988, 37, 785.

30. Vosko, S. H.; Wilk, L.; Nusair, M. Can. J. Phys. 1980, 58, 1200.

31. Frisch, M. J.; Head-Gordon, M.; Pople, J. A. Chem. Phys. Lett. 1990, 166, 281.

[32. Csaszar, P.; Pulay, P. J. Mol. Struct. 1984, 114, 31.

33. Peng, C.; Schlegel, H. Isr. J. Chem. 1994, 33, 449.

34. Schachtschneider, J. H.; Mortimer, F. S. Vibrational Analysis of Polyatomic Molecules. VI FORTRAN IV Programs for Solving the Vibrational Secular Equation and for the Least-Squares Refinement of Force Constants, Project No. 31450. Structural Interpretation of Spectra; Shell Development: Houston, TX, 1965.

35. Reva, I. D.; Stepanian, S. G.; Adamowicz, L.; Fausto, R. Chem. Phys. Lett. 2003, $374,631$.

36. Lopes Jesus, A. J.; Rosado, M. T. S.; Reva, I.; Fausto, R.; Eusébio, M. E. S.; Redinha, J. S. J. Phys. Chem. A 2008, 112, 4669.

37. Rosado, M. T. S.; Lopes Jesus, A. J.; Reva, I. D.; Fausto, R.; Redinha, J. S. J. Phys. Chem. A 2009, 113, 7499.

38. Dobrowolski, J. C.; Kolos, R.; Sadlej, J.; Mazurek, A. P. Vib. Spectrosc. 2002, 29, 261.

39. Ware, E. Chem. Rev. 1950, 46, 403.

40. Schaber, P. M.; Colson, J.; Higgins, S.; Thielen, D.; Anspach, B.; Brauer, J. Thermochim. Acta 2004, 424, 131.

41. Tokmakov, I. V.; Alavi, S.; Thompson, D. L. J. Phys. Chem. A 2006, 110, 2759.

42. Bohn, R. B.; Andrews, L. J. Phys. Chem. 1989, 93, 3974.

43. Bossa, J. B.; Duvernay, F.; Theulé, P.; Borget, F.; Chiavassa, T. Chem. Phys. 2008 354, 211.

44. Lundell, J.; Krajewska, M.; Räsänen, M. J. Phys. Chem. A 1998, 102, 6643.

45. Teles, J. H.; Maier, G.; Hess, B. A., Jr.; Schaad, L. J.; Winnewesser, M.; Winnewisser, B. P. Chem. Ber. 1989, 122, 753.

46. Coffey, M. J.; Berghout, H. L.; Woods, E., III; Crim, F. F. J. Chem. Phys. 1999, 110, 10850.

47. McLean, A. D.; Loew, G. H.; Berkowitz, D. S. J. Mol. Spectrosc. 1977, 64, 184.

48. Cugley, P. A.; Pullin, A. D. E. Chem. Phys. Lett. 1973, 19, 203.

49. Stewart, J. E. J. Chem. Phys. 1957, 26, 248.

50. Rozenberg, M.; Shoham, G.; Reva, I. D.; Fausto, R. Spectrochim. Acta A 2004, 60, 2319.

51. Rozenberg, M.; Shoham, G.; Reva, I. D.; Fausto, R. Spectrochim. Acta A 2004, 60, 463.

52. Rozenberg, M.; Shoham, G.; Reva, I. D.; Fausto, R. Spectrochim. Acta A 2003, 59, 3253.

53. Rozenberg, M.; Shoham, G.; Reva, I. D.; Fausto, R. Phys. Chem. Chem. Phys. 2005, 7, 2376 . 